\title{
Effects of Alcohol Vapors and Oxygen Stress on Superficial Scald and Red Color of Stored 'Delicious' Apples
}

\author{
F. Ghahramani and K.J. Scott ${ }^{1}$ \\ Department of Food Science and Technology, The University of New South \\ Wales, Sydney 2052, Australia
}

\section{R. Holmes ${ }^{2}$ \\ Institute for Horticultural Development, Private Bag 15, SE Mail Centre, Victoria 3176, Australia}

Additional index words. Butan-1-ol, ethanol, propan-1-ol, pentan-1-ol, Malus $\times$ domestica, physiological disorders, soft scald, postharvest physiology

\begin{abstract}
Delicious' (Malus $\times$ domestica Borkh.) apples were kept in sealed polyethylene bags (thickness $0.05 \mathrm{~mm}$ ) and exposed to ethanol, propan-1-ol, butan-1-ol, and pentan1-ol during storage at $0^{\circ} \mathrm{C}$. Rates of application varied from 1.85 to $120 \mathrm{mmol} \cdot \mathrm{kg}^{-1}$. Complete control of superficial scald was achieved using $30 \mathrm{mmol} \cdot \mathrm{kg}^{-1}$ of fruit with butan-1-ol or propan-1-ol; ethanol required $120 \mathrm{mmol} \cdot \mathrm{kg}^{-1}$ to control the disorder, but at this concentration, purpling of the red skin occurred. Butan-1-ol and propan-1-ol did not affect the color. Pentan-1-ol caused severe skin injury resembling soft or deep scald of 'Jonathan' apples. Apples were also kept in high purity $\mathrm{N}$ at $20^{\circ} \mathrm{C}$ for up to 8 days before storage at $0{ }^{\circ} \mathrm{C}$. Complete control of scald occurred with a 6- or 8-day exposure to $\mathrm{N}$. Control of scald appears to be due to the accumulation of ethanol during exposure to $N$. Nitrogen treatments did not affect skin color.
\end{abstract}

Superficial scald is a physiological disorder of several cultivars of apples and pears (Pyrus communis L.). It is more severe following a hot dry summer and develops after cold storage. The disorder appears as a brown discoloration on the skin of the fruit after removal to higher temperatures. Studies on scald have been very extensive and have been reviewed by Smock (1961), Meigh (1970), and Ingle and D'Souza (1989). Recently, Scott et al. (1995) found that scald of 'Granny Smith' apples could be controlled by exposing fruit to ethanol vapor during storage. Ghahramani and Scott (1998a) found that ethanol vapor reduced the accumulation of $\alpha$-farnesene and markedly reduced its oxidation to conjugated trienes. Ethanol does not seem to have a specific action, as some alcohols of high molecular weight are also effective (Ghahramani et al., 1999). Ghahramani and Scott (1998b) also found that scald was also controlled in the highly susceptible Granny Smith cultivar by subjecting the apples to a period of low oxygen stress during cold storage or at $20{ }^{\circ} \mathrm{C}$ before storage. Under these conditions, endogenous ethanol accumulated in sufficient amounts to control scald.

Current control measures for scald are based on the work of Smock $(1957,1961)$ who

\footnotetext{
Received for publication 29 Sept. 1999. Accepted for publication 14 Feb. 2000. The cost of publishing this paper was defrayed in part by the payment of page charges. Under postal regulations, this paper therefore must be hereby marked advertisement solely to indicate this fact.

${ }^{1}$ To whom requests for reprints should be addressed. Fax: +61-2-6372-4264.
}

containing $4 \mathrm{~g}$ of vermiculite as a carrier, were placed above the fruit and the appropriate amount of ethanol, propan-1-ol, butan-1ol, or pentan-1-ol was added to the vermiculite and the bags were sealed with rubber bands. Seven levels of each alcohol (1.85 to $120 \mathrm{mmol} \cdot \mathrm{kg}^{-1}$ fresh weight of apple) plus several units with no alcohol in a bag as controls. The bags remained sealed throughout storage. Fruit were removed from the bags after 16 weeks, held at $20{ }^{\circ} \mathrm{C}$ for 1 week, then examined for scald.

In Expt. 2, fruit were placed in 25-L drums at $20^{\circ} \mathrm{C}$, the drums were sealed, and high purity $\mathrm{N}_{2}$ was humidified by passage through water and metered into the drums. The rate of addition $\left(2-6 \mathrm{~L} \cdot \mathrm{h}^{-1}\right)$ was adjusted through storage so that the $\mathrm{CO}_{2}$ concentration did not rise above $1 \%$. The $\mathrm{N}_{2}$ was applied for $0,1,2$, $3,4,6$, and $8 \mathrm{~d}$ at $20^{\circ} \mathrm{C}$. The drums were then opened, the fruit packed into single layer trays and held in air at $0{ }^{\circ} \mathrm{C}$ for 16 weeks. Scald was measured after a further week at $20{ }^{\circ} \mathrm{C}$.

In both experiments, scald was assessed using a 6 -point scale, where $0=$ no scald and $5=$ very severe scald (Hall et al., 1961). The mean scores were calculated by multiplying the number of affected fruit by the appropriate rating, adding these values together and dividing by the number of fruit in the experimental unit. The mean score was used for statistical analysis. Regression analysis was used for Fig. 1; other comparisons were made using analysis of variance and mean separations detected using LSDS. Abnormal purpling of the red color was rated as present or absent.

\section{Results}

pean community (E.C.) and Asia, no longer permit the use of these chemicals (Truter et al., 1994). The future of DPA is uncertain in the United States and there is no satisfactory alternative. Experiments with treatments such as storage in low $\mathrm{O}_{2}$ have been inconclusive (Lau, 1997a and 1997 b).

The present study is part of a project aimed at finding a commercial alternative to DPA. While the use of ethanol on 'Granny Smith' does not seem to produce adverse effects, little is known about the effects on other cultivars. Health and regulatory authorities will require extensive evidence of ethanol's effectiveness before alcohol will be approved for commercial use. This paper also reports on the effects of ethanol on purpling of the red skin of 'Delicious' apples.

\section{Materials and Methods}

'Delicious' apples were harvested at Bathurst, New South Wales, 1-2 weeks before the commercial harvest, as early harvesting is known to favor scald development. Fruit were randomized in the orchard into experimental units of 20 fruit. In each experiment, four replicates of 20 fruit were obtained from a separate group of 10 trees in the same orchard. In Expt. 1, each experimental unit was precooled for $7 \mathrm{~d}$ at $0{ }^{\circ} \mathrm{C}$ then placed in a single layer in a nonperforated polyethylene bag (thickness $0.05 \mathrm{~mm}$ ). Four cups, each
Ethanol, propan-1-ol, and butan-1-ol controlled severe superficial scald on 'Delicious' (Fig. 1). Ethanol fully controlled scald when applied at $120 \mathrm{mmol} \cdot \mathrm{kg}^{-1}$ fruit and when applied at $60 \mathrm{mmol} \cdot \mathrm{kg}^{-1}$ ethanol produced full control in three replicates. Slight scald occurred in the $4^{\text {th }}$ replicate. Propan-1ol and butan-1-ol gave complete control when applied at $30 \mathrm{mmol} \cdot \mathrm{kg}^{-1}$; pentan-1-ol induced severe skin injury and the incidence was so severe that scald, if present, was completely obscured. This injury closely resembled soft scald of 'Jonathan' (Hall and Scott, 1977). Ethanol applied at $60 \mathrm{mmol} \cdot \mathrm{kg}^{-1}$ and above produced an unattractive purplish color on the red areas of the skin of all the fruit. Propan-1-ol and butan-1-ol did not affect the color of the skin.

Exposure of 'Delicious' apples to a $\mathrm{N}_{2}$ atmosphere at $20{ }^{\circ} \mathrm{C}$ resulted in the accumulation of ethanol. This accumulation was linearly related to the period of exposure; $\mathrm{y}=0.3168 \mathrm{x}-0.1321 ; r^{2}=0.9978$. Thus, ethanol increased by $0.32 \mathrm{mg} \cdot \mathrm{mL}^{-1}$ (7 $\mathrm{mmol} \cdot \mathrm{kg}^{-1}$ ) of juice with each additional day that the apples were exposed to $\mathrm{N}_{2}$. After $8 \mathrm{~d}$, the $\mathrm{N}_{2}$ treatment had accumulated $50 \mathrm{mmol}$ ethanol/kg of juice. Under these conditions, scald was fully controlled after exposure to $\mathrm{N}_{2}$ for $6 \mathrm{~d}$. There was a substantial reduction in scald after exposure for $2 \mathrm{~d}$ (Fig. 2). 


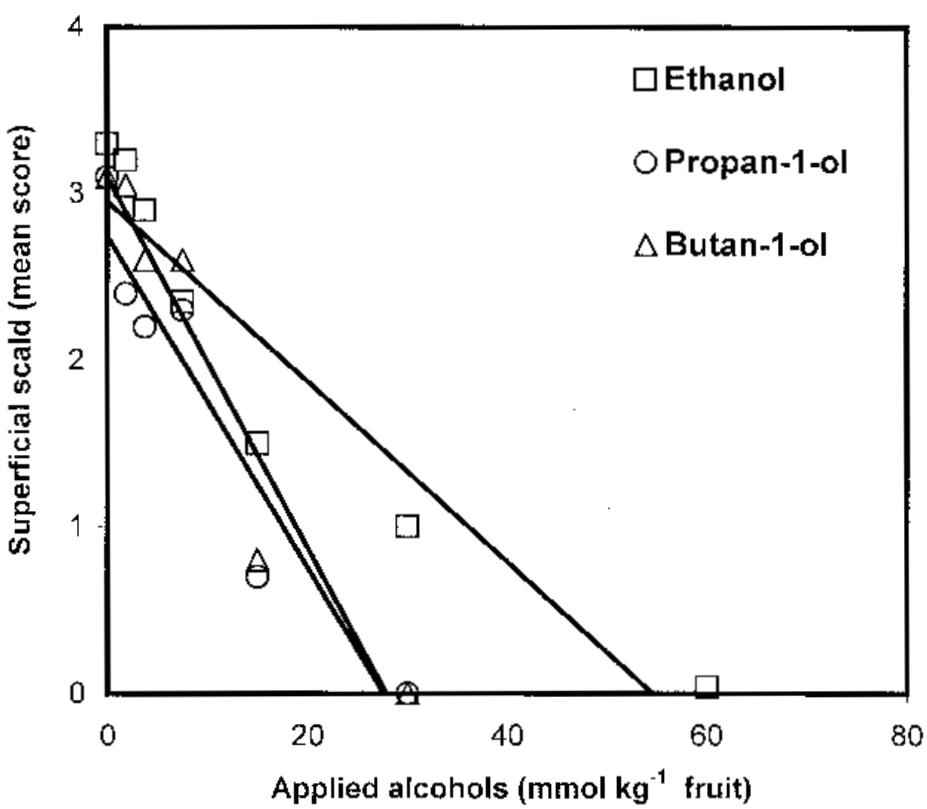

Fig. 1. Control of superficial scald of 'Delicious' apples with exposure to ethanol, propan-1-ol and butan1 -ol vapor during storage at $0{ }^{\circ} \mathrm{C}$. The regression equations are: ethanol $\mathrm{y}=-54.334 \mathrm{x}+2.9655 r^{2}=$ 0.8964 ; propan-1-ol $\mathrm{y}=-99.343 \mathrm{x}+2.7457 r^{2}=0.9082$; butan-1-ol $\mathrm{y}=-111.2 \mathrm{x}+3.1014 r^{2}=0.9294$.

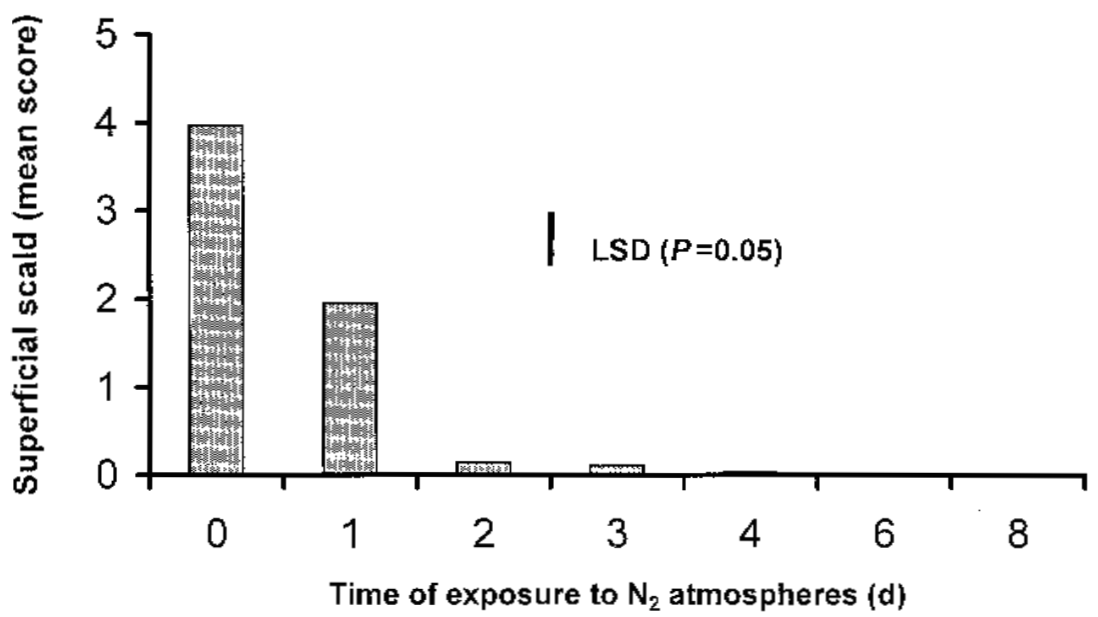

Fig. 2. Superficial scald of 'Delicious' apples after 16 weeks of storage at $0{ }^{\circ} \mathrm{C}$ and a further week at $20^{\circ} \mathrm{C}$. Apples were exposed to $\mathrm{N}_{2}$ at $20^{\circ} \mathrm{C}$ prior to storage in air at $0{ }^{\circ} \mathrm{C}$.

\section{Discussion}

These results demonstrate the need to thoroughly investigate the effects of ethanol vapor on other cultivars before recommendations are made for its commercial use, for control of scald. We do not know how susceptible other red cultivars are to purpling. In 'Delicious', purpling occurred at about the level of ethanol application that controlled scald. Thus purpling in 'Delicious' might be controlled by using the maximum amount of ethanol that does not induce purpling, combined with some other treatment that reduces scald but does not fully control the disorder. Controlled atmosphere may be such a treatment, but very low oxygen should be avoided as this can itself cause purpling (Lau, 1997b). Alternatively, ethanol vapor may be a means to greatly limit the concentration of DPA ap- that showing the disorder, making soft scald easy to distinguish from other apple scalds. Hexan-1-ol induces soft scald in 'Jonathan' (Wills and Scott, 1970). Surprisingly, DPA controls soft scald (Wills and Scott, 1982). Thus, either the basic mechanisms for the formation of both types of scald may be related, or DPA has a broad spectrum of action. Higher alcohols, such as $\alpha$-terpineol (Ghahramani and Scott, 1998a) were ineffective in controlling superficial scald on 'Granny Smith', possibly because of low volatility. Other volatile compounds may be worth screening for their effects on superficial and soft scalds. In further studies, determining what happens to the alcohols when absorbed by the fruit would seem worthwhile.

\section{Literature Cited}

Ghahramani, F. and K.J. Scott. 1998a. The action of ethanol in controlling superficial scald of apples. Austral. J. Agr. Res. 49:199-205.

Ghahramani, F. and K.J. Scott. 1998b. Oxygen stress of 'Granny Smith' apples in relation to superficial scald, ethanol, $\alpha$-farnesene, and conjugated trienes. Austral. J. Agr. Res. 49:207-210.

Ghahramani, F., K.J. Scott, K. Buckle, and J. Paton. 1999. A comparison of the effects of ethanol and higher alcohols for the control of superficial scald of apples. J. Hort. Sci. Biotechnol. 74:87-93.

Hall, E.G. and K.J. Scott. 1977. Storage and marketing diseases of fruit, p. 55. Commonwealth Scientific and Industrial Research Organisation. Div. of Food Research. North Ryde, Australia.

Hall, E.G., K.J. Scott, and G.G. Coote. 1961. Control of superficial scald on Granny Smith apples with diphenylamine. Austral. J. Agr. Res. 12:834-852.

Ingle, M. and M.C. D’Souza. 1989. Physiology and control of superficial scald of apples: A review. HortScience 24:28-31.

Lau, O.L. 1997a. The effectiveness of $0.7 \%$ oxygen to attenuate scald symptoms in 'Delicious' apples is influenced by harvest maturity and cultivar strain. J. Amer. Soc. Hort. Sci. 122:691-697.

Lau, O.L. 1997b. Initial low oxygen stress offers no scald control benefits to Starkinson 'Delicious' apples in $0.7 \mathrm{kPa} \mathrm{O}_{2}$ storage. HortScience 32:1239-1241.

Meigh, D.F. 1970. Apple scald, p. 557-567. In A.C. Hulme (ed.). The biochemistry of fruit and their products. Academic, London.

Nicols, W.C. and M.E. Patterson. 1987. Ethanol accumulation and post storage quality of 'Delicious' apples during short term, low- $\mathrm{O}_{2}$, CA storage. HortScience 22:89-92.

Scott, K.J., C.M.C. Yuen, and F. Ghahramani. 1995. Ethanol vapour-A new anti scald treatment for apples. Postharvest Biol. Technol. 6:201-208.

Smock, R.M. 1957. A comparison of treatments for control of apple scald disease. Proc. Amer. Soc. Hort. Sci. 69:91-100.

Smock, R.M. 1961. Methods of scald control on the apple. Cornell Univ. Agr. Expt. Sta. Bul. No. 970.

Truter, A.B., J.C. Combrink, and S.A. Burger. 1994. Control of superficial scald in 'Granny Smith' apples by ultra low and stress levels of oxygen as an alternative to diphenylamine. J. Hort. Sci. 69:681-587.

Wills, R.B.H. and K.J. Scott. 1970. Hexanol and hexyl acetate and soft scald of apples. Phytochemistry 9:1035-1036.

Wills, R.B.H. and K.J. Scott. 1982. Use of dips containing diphenylamine and edible oils to reduce soft scald of apples. HortScience 17:964965. 